\title{
EVALUATION OF FAILURE PATTERN ON A FLEXIBLE PAVEMENT A CASE STUDY OF WARAWA LOCAL GOVERNMENT KANO STATE
}

\author{
A.B. Shehu1, A. Zaid, A.B Abdulkarim, F.L Zubair, S.H. Jido \\ Nigeria Building and Road Research Institution (NBRRI), Northwest Zonal Office, Kano \\ M. Garba, K.A. Farouk \\ Civil Engineering Department, Kano University of Science and Technology Wudil
}

\begin{abstract}
The most used mode of transportation in Nigeria is road while flexible pavement is the most constructed on the roads. This research work is all about carefully assessing the condition of the flexible pavement on some selected roads, determine the surface rating, identifying various type of flexible pavement failure and suggest an appropriate preventive maintenance treatment on the selected roads in Warawa Local Government area of Kano State, North -western Nigeria. The visual assessments of the pavement were carried out through reconnaissance survey and Pavement Condition Survey of the selected roads. Distress feature such as cracking, raveling and potholes were taken from the failed portion of the roads and their percentage and weighted failure of each failure type were determined. After the thorough assessment of the pavements on selected roads it can be concluded that the percentage of weighted failures on the roads are cracking $=2.098$, potholes $=9.036$, and raveling $=0.016$ with the total weighted failure as 11.474. Finally the paper concludes with recommendation which includes that, the rating indices, which were developed using appropriate method, should serve as a guide to any maintenance and other relevant agencies in finding out suitable treatment to these defects. It is also recommended to implore more sophisticated equipment and methods. This effort will help in covering large distance road and consequently more realistic results could be obtained. It is further recommended that the road need full depth reconstruction with extensive base repair using the rating score obtained.
\end{abstract}

Keywords: Assessment, Failure Pattern, Flexible Pavement, Warawa, Kano.

\section{INTRODUCTION}

Pavement failure is defined in terms of decreasing serviceability caused by the development of surface distresses such as cracks, potholes and ruts, Chukweze (1988). They reported that before going into the maintenance strategies, highway engineers must look into the causes of failures of bituminous pavements. They found that failures of bituminous pavements are caused due to many reasons or combination of reasons. It has been seen that only three parameters i.e. unevenness index, pavement cracking and rutting are considered while other distresses have been omitted while going for maintenance operations.

Failure of pavement roads is a common occurrence in Nigeria. Various reasons are known to induce highway pavement failure, Chukweze (1988). However, the pertinent factors influencing failure of highway pavements cannot be controlled without evaluating the geotechnical properties of the soil materials used in construction of the roads. Jegede (1995), Bello and Adegoke (2010), observed that the soil material properties at the failed sections of the road have usually not been thoroughly investigated. In addition, according to Yoder and Witczak (1975) there are two types of pavement distress, or failure. The first is a structural failure, in which a collapse of the entire structure or a breakdown of one or more of the pavement components renders the pavement incapable of sustaining the loads imposed on its surface. The second type of failure is a functional failure; it occurs when the pavement, due to its roughness, is unable to carry out its intended function without causing discomfort to drivers or passengers or imposing high stresses on vehicles. The cause of these failure conditions may be due to inadequate 


\section{International Journal of Engineering Applied Sciences and Technology, 2020 \\ Vol. 4, Issue 12, ISSN No. 2455-2143, Pages 28-35 \\ Published Online April 2020 in IJEAST (http://www.ijeast.com)}

maintenance, excessive loads, climatic and environmental conditions, poor drainage leading to poor sub grade conditions, and disintegration of the component materials. Excessive loads, excessive repetition of loads and high tire pressures can cause either structural or functional failures Kumar and Gupta (2010).

According to Woods and Adcox (2004), pavement failure may be considered as structural, functional, or materials failure, or a combination of these factors. Structural failure is the loss of load carrying capability, where the pavement is no longer able to absorb and transmit the wheel loading through the structure of the road without causing further deterioration. Functional failure is a broader term, which may indicate the loss of any function of the pavement such as skid resistance, structural capacity, and serviceability or passenger comfort. Materials failure occurs due to the disintegration or loss of material characteristics of any of the component materials. Caltrans (2001), categorized the main types of pavement failures as either deformation failures or surface texture failures. Deformation failures include corrugations, depressions, and potholes, rutting and shoving. These failures may be due to either traffic (load associated) or environmental (non-load associated) influences. It may also reflect serious underlying structural or material problems that may lead to cracking. Surface texture failures include bleeding, cracking, polishing, stripping and raveling. These failures indicate that while the road pavement may still be structurally sound, the surface no longer performs the function it is designed to do., which is normally to provide skid resistance, a smooth running surface and water tightness. Other miscellaneous types of pavement failures include edge defects, patching and roughness.

The Cracking consists of visible discontinuities in surface and can be an indication of the pavement's structural condition and serious, Jain and Kumar (1998). The main problem with cracks is that they allow moisture into pavement, giving accelerated deterioration of pavement. Cracks can occur in a wide variety of patterns. They may result from a large number of causes, but generally are the result of either ageing and embrittlement of surfacing, environmental conditions, structural or fatigue failure of the pavement, or any other causes, Jain and Kumar
(1998). The formation of cracks in the pavement surface causes numerous problems such as discomfort to the users, reduction of safety, etc. In addition to the above, intrusion of water causing reduction of the strength in lower layers as well as lowering of bearing capacity of sub grade soil by pumping of soil particles through the cracks is also a major problem associated with the pavements, Ahmed (2008) . This leads to the progressive degradation of the road pavement structure in the neighborhood of the cracks. The origin of cracks differs by their shapes, configuration, and amplitude of loading, movement of traffic and rate of deformation. In addition to the above, intrusion of water causing reduction of the strength in lower layers as well as lowering of bearing capacity of subgrade soil by pumping of soil particles through the cracks is also a major problem associated with the pavements, Ola (1978).

It is perhaps that transportation network connecting the Central Business District (CBD), the industrialize areas, rural areas (i.e. were food and manufacturing product are produces) and the residential environment enhances the socio-economic development, growth and progress of a country in general. In Nigeria road type have been successively developing/ improving over the early ninety to date i.e. initially from unpaved road (e.g. bush path or track) or pave road (e.g. flexible or rigid pavement) and others types of modern highway, Bello; Ige and Adebanjo, (2015), Bello and Adegoke (2010).

Flexible pavement is the road type adopted in most Nigeria road today and government spend huge amount of its national fund for the planning, designing, constructing and maintenance of such road facilities. So therefore, proper attention should be given to such road as to preserve and prevent early failure of the road in order to attain its useful design life.

\subsection{Description of the Study Area}

Warawa is a Local Government Area in Kano State, Nigeria. Its headquarters are in the town of Warawa; and it is located at longitude $7^{0} 55^{\prime}$ Nand latitude $4^{0} 40^{\prime}$ Ewith a total land mass of $114 \mathrm{~km}^{2}$ and a population of 96,748 at the 2006 census. The geologic formation of the study area falls within the basement complex of the North-Western Nigeria, which consists of the amphibolites, migmatite gneisses, granite and pegmatites. 


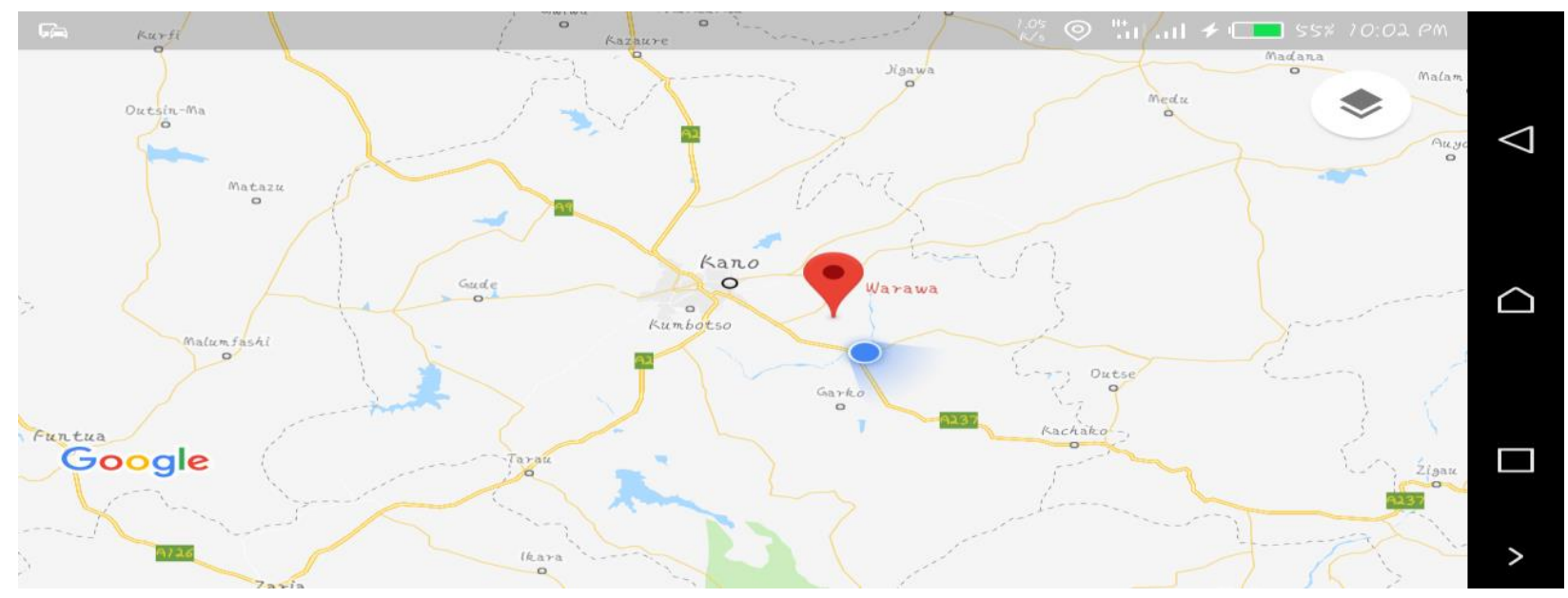

II. MATERIALS AND METHOD

As we are assessing the failure rate/pattern on the pavement, two methods were used i.e. objective and subjective assessments. But in our case, we are adopting the objective assessments, which entail the following steps: Reconnaissance survey, Pavement condition survey.

Visual condition surveys were carried out in collecting relevant data using objective assessments method. In order to avoid unnecessary mistakes and to understand the present condition of the study area, $100 \mathrm{~m}$ tape was used to measure the total distance of the route of study. After the above-mentioned exercise, then the inventories of the road (i.e. types of road failure) were taken using relevant engineering tools. The data collected were analyzed to predict appropriate maintenance measures.

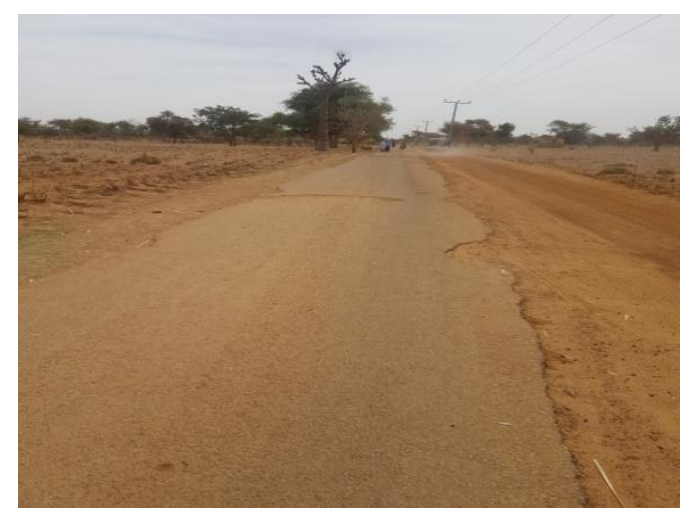

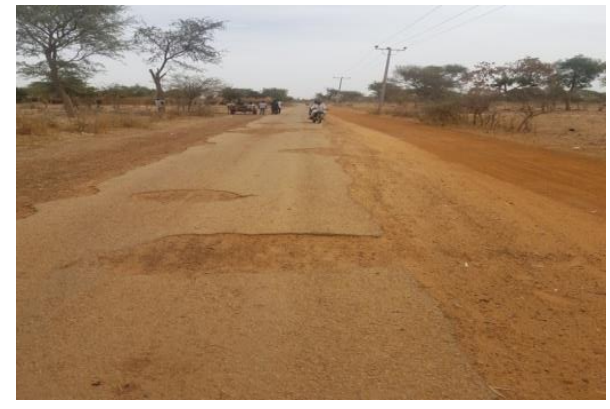

Fig: 3.2: Raveling (from visual site survey)

\subsection{Empirical Equation Used In Objective} Assessment

The following equations are used to calculate the overall surface rating of bituminous pavement; (DOT Distress identification manual, 2003)

$$
\begin{aligned}
& \text { Percentage of crack (\%) } \\
& =\frac{\text { length of cracks observed }}{\text { length of the section being surveyed }} \\
& \times 100
\end{aligned}
$$

Table 2.0 Bituminous Pavement-Weighting Factors

\begin{tabular}{|l|l|}
\hline Failure Type & Weighting Factor \\
\hline Cracking (alligator, block & 0.25 \\
\hline
\end{tabular}


International Journal of Engineering Applied Sciences and Technology, 2020

Vol. 4, Issue 12, ISSN No. 2455-2143, Pages 28-35

Published Online April 2020 in IJEAST (http://www.ijeast.com)

\begin{tabular}{|l|l|}
\hline and end cracking) & \\
\hline Rutting & 0.15 \\
\hline Raveling & 0.02 \\
\hline Pothole/Patching & 0.04 \\
\hline
\end{tabular}

( DOT Distress identification manual, 2003)

Table 2.1 Surface Rating Of Bituminous Pavement

\begin{tabular}{|l|l|}
\hline Total Weighted Percent & Surface Rating (SR) \\
\hline 0 & 4.0 \\
\hline 1 & 3.8 \\
\hline 2 & 3.6 \\
\hline 3 & 3.4 \\
\hline 4 & 3.2 \\
\hline 5 & 3.0 \\
\hline 6 & 2.9 \\
\hline 7 & 2.8 \\
\hline 8 & 2.7 \\
\hline 9 & 2.6 \\
\hline 10 & 2.5 \\
\hline 11 & 2.4 \\
\hline 12 & 2.3 \\
\hline 13 & 2.2 \\
\hline 14 & 2.1 \\
\hline 15 & 2.0 \\
\hline $16-17$ & 1.9 \\
\hline 18 & 1.8 \\
\hline $19-20$ & 1.7 \\
\hline & Wowever \\
\hline
\end{tabular}

. However, this effort was to develop suitable solutions to different types of problems encountered on the road surface.

\begin{tabular}{|l|l|}
\hline 21 & 1.6 \\
\hline $22-23$ & 1.5 \\
\hline 24 & 1.4 \\
\hline $25-26$ & 1.3 \\
\hline 27 & 1.2 \\
\hline $28-29$ & 1.1 \\
\hline $30-33$ & 1.0 \\
\hline $34-40$ & 0.9 \\
\hline $41-47$ & 0.8 \\
\hline $48-54$ & 0.7 \\
\hline $55-61$ & 0.6 \\
\hline $62-68$ & 0.5 \\
\hline $69-75$ & 0.4 \\
\hline $76-82$ & 0.3 \\
\hline $83-89$ & 0.2 \\
\hline $90-96$ & 0.1 \\
\hline $97-100$ & 0.0 \\
\hline
\end{tabular}

\subsection{Treatment Measures For Flexible Pavement}

Pavement management systems involves collection of data and general assessment of roads characteristics such as surface condition, roughness, e.t.c surface condition remains the most essential element in any pavement management system, therefore relevant agencies uses simplified rating system presented in table 3.0 and 4.0

Table 2.2: Treatment Measures

\begin{tabular}{|c|c|c|c|}
\hline Overall rating & Treatment Measures & \multicolumn{2}{|c|}{ Surface structure } \\
\hline 10 & \multirow[t]{2}{*}{ Routine maintenance } & \multicolumn{2}{|c|}{ Excellent } \\
\hline 9 & & \multicolumn{2}{|c|}{ Very good } \\
\hline 8 & \multirow[t]{2}{*}{ Resealing and restoration of skid resistance } & Fair & \multirow[t]{2}{*}{ Good } \\
\hline 7 & & Poor & \\
\hline 6 & \multirow{2}{*}{$\begin{array}{l}\text { Surface restoration-carry out localized repairs and treat with surface } \\
\text { treatment or thin overlay }\end{array}$} & Fair & \multirow[t]{2}{*}{ Good } \\
\hline 5 & & Poor & \\
\hline 4 & \multirow{2}{*}{$\begin{array}{l}\text { Surface overlay-required to strengthened road. Localized patching and } \\
\text { repairs required prior to overlay }\end{array}$} & \multirow{2}{*}{\multicolumn{2}{|c|}{ Poor overall }} \\
\hline 3 & & & \\
\hline 2 & \multirow{2}{*}{$\begin{array}{l}\text { Road construction-need full depth reconstruction with extensive base } \\
\text { repair }\end{array}$} & \multirow{2}{*}{\multicolumn{2}{|c|}{$\begin{array}{l}\text { Very poor overall } \\
\text { Failed overall }\end{array}$}} \\
\hline 1 & & & \\
\hline
\end{tabular}

(DOT Distress identification manual, 2003)

Table 2.3 Rating System

\begin{tabular}{|l|l|l|}
\hline $\begin{array}{l}\text { Overall } \\
\text { rating }\end{array}$ & $\begin{array}{l}\text { Primary rating } \\
\text { indicators }\end{array}$ & $\begin{array}{l}\text { Secondary } \\
\text { rating indicators }\end{array}$ \\
\hline 10 & No visible defects & $\begin{array}{l}\text { Road surface in } \\
\text { perfect }\end{array}$ \\
\hline
\end{tabular}

\begin{tabular}{|l|l|l|}
\hline & & $\begin{array}{l}\text { condition, like } \\
\text { new. }\end{array}$ \\
\hline 9 & $\begin{array}{l}\text { Less than 10\% of } \\
\text { surface with surface } \\
\text { defects }\end{array}$ & $\begin{array}{l}\text { Road surface in } \\
\text { very good } \\
\text { condition. }\end{array}$ \\
\hline 8 & $10 \%$ to 30\% of & Little or no \\
\hline
\end{tabular}


International Journal of Engineering Applied Sciences and Technology, 2020

Vol. 4, Issue 12, ISSN No. 2455-2143, Pages 28-35

Published Online April 2020 in IJEAST (http://www.ijeast.com)

\begin{tabular}{|c|c|c|}
\hline & $\begin{array}{l}\text { surface with surface } \\
\text { defects }\end{array}$ & other defects \\
\hline 7 & $\begin{array}{l}\text { Greater than } 30 \% \text { of } \\
\text { surface with surface } \\
\text { defects }\end{array}$ & $\begin{array}{l}\text { Little or no } \\
\text { other defects. } \\
\text { Old surface with } \\
\text { aged appearance }\end{array}$ \\
\hline 6 & $\begin{array}{l}\text { Less than } 20 \% \\
\text { cracking may be } \\
\text { present. } \\
\text { Patching generally in } \\
\text { fair condition. } \\
\text { May be out of shape } \\
\text { requiring in some } \\
\text { reduction in driver } \\
\text { speed. }\end{array}$ & $\begin{array}{l}\text { Surface defects } \\
\text { may be present. } \\
\text { No structural } \\
\text { distress }\end{array}$ \\
\hline 5 & $\begin{array}{l}\text { Greater than } 20 \% \\
\text { cracking present. } \\
\text { Patching generally in } \\
\text { fair condition. } \\
\text { Out of shape } \\
\text { requiring reduction in } \\
\text { driver speed. } \\
\text { Very localized } \\
\text { structural distress(less } \\
\text { than 5sq.m of } \\
\text { surface) may be } \\
\text { present. }\end{array}$ & $\begin{array}{l}\text { Surface defects } \\
\text { may be present. }\end{array}$ \\
\hline 4 & $\begin{array}{l}\text { Rutting or alligator } \\
\text { cracking for } 5 \% \text { to } \\
25 \% \text { of surface. } \\
\text { Short lengths of edge }\end{array}$ & $\begin{array}{l}\text { Others defects } \\
\text { may be present }\end{array}$ \\
\hline
\end{tabular}

\begin{tabular}{|c|c|c|}
\hline & $\begin{array}{l}\text { break up/cracking. } \\
\text { Small no of potholes. }\end{array}$ & \\
\hline 3 & $\begin{array}{l}\text { Significant areas of } \\
\text { structural distress. } \\
\text { Rutting or alligator } \\
\text { cracking for } 25 \% \text { to } \\
50 \% \text { of surface. } \\
\text { Significant } \\
\text { continuous length } \\
\text { with edge breakup/ } \\
\text { cracking frequent } \\
\text { potholes. }\end{array}$ & $\begin{array}{l}\text { Others defects } \\
\text { may be present. }\end{array}$ \\
\hline 2 & $\begin{array}{l}\text { Large areas of } \\
\text { structural distress. } \\
\text { Rutting or alligator } \\
\text { cracking for over } \\
50 \% \text { of surface. } \\
\text { Severe rutting (over } \\
75 \mathrm{~mm} \text { deep). } \\
\text { Extensive patching in } \\
\text { very poor condition. } \\
\text { Many potholes. }\end{array}$ & $\begin{array}{l}\text { Very difficult to } \\
\text { drive on. }\end{array}$ \\
\hline 1 & $\begin{array}{l}\text { Severe structural } \\
\text { distress with } \\
\text { extensive loss of } \\
\text { pavement surface. } \\
\text { Road disintegration } \\
\text { of surface. } \\
\text { Many large and deep } \\
\text { potholes. } \\
\text { Patching in failed } \\
\text { condition. }\end{array}$ & $\begin{array}{ll}\text { Severe } & \\
\text { deterioration } \\
\text { virtually un } \\
\text { drivable }\end{array}$ \\
\hline
\end{tabular}

(Adapted PASER Asphalt Roads manual, 2002)

\section{PRESENTATION, ANALYSIS AND DISCUSSION OF RESULT}

Results of the Pavement Condition Survey (Warawa Junction Road To Laraba Road).

Table 3.0 Calculation of Weighted Failure (Cracking)

\begin{tabular}{|l|l|l|l|}
\hline $\begin{array}{l}\text { Chainage } \\
(\mathrm{m})\end{array}$ & $\begin{array}{l}\text { Cracking } \\
(\mathrm{m})\end{array}$ & $\begin{array}{l}\text { Percentage } \\
\text { of crack (\%) }\end{array}$ & $\begin{array}{l}\text { Weighted } \\
\text { failure= } \\
\left(\% \quad \begin{array}{l}\% \\
\text { crack of } \\
\times 0.25)\end{array}\right.\end{array}$ \\
\hline $\begin{array}{l}0+080- \\
0+100\end{array}$ & 30 & 0.28 & 0.070 \\
\hline $0+240-$ & 25 & 1.10 & 0.275 \\
\hline
\end{tabular}

\begin{tabular}{|l|l|l|l|}
\hline $0+260$ & & & \\
\hline $\begin{array}{l}0+300- \\
0+320\end{array}$ & 30 & 0.28 & 0.070 \\
\hline $\begin{array}{l}1+020- \\
1+040\end{array}$ & 29 & 0.26 & 0.065 \\
\hline $\begin{array}{l}1+520- \\
1+540\end{array}$ & 27 & 0.24 & 0.060 \\
\hline $\begin{array}{l}2+620- \\
2+640\end{array}$ & 30 & 0.28 & 0.070 \\
\hline $\begin{array}{l}2+940- \\
2+960\end{array}$ & 25 & 1.10 & 0.275 \\
\hline $\begin{array}{l}3+140- \\
3+160\end{array}$ & 29 & 0.26 & 0.060 \\
\hline $\begin{array}{l}3+900- \\
3+920\end{array}$ & 30 & 0.28 & 0.070 \\
\hline $4+200-$ & 26 & 0.23 & 0.058 \\
\hline
\end{tabular}


International Journal of Engineering Applied Sciences and Technology, 2020

Vol. 4, Issue 12, ISSN No. 2455-2143, Pages 28-35

Published Online April 2020 in IJEAST (http://www.ijeast.com)

\begin{tabular}{|l|l|l|l|}
\hline $4+220$ & & & \\
\hline $4+320-$ & 25 & 1.10 & 0.275 \\
$4+340$ & & & \\
\hline $5+240-$ & 25 & 1.10 & 0.275 \\
$5+260$ & & & \\
\hline $\begin{array}{l}6+560- \\
6+580\end{array}$ & 30 & 0.28 & 0.070 \\
\hline $7+120-$ & 27 & 0.24 & 0.060 \\
$7+140$ & & & \\
\hline $\begin{array}{l}8+640- \\
8+660\end{array}$ & 30 & 0.28 & 0.070 \\
\hline $8+820-$ & 25 & 1.10 & 0.275 \\
$8+840$ & & & \\
\hline
\end{tabular}

\begin{tabular}{|l|l|l|l|}
\hline $\begin{array}{l}10+040- \\
10+060\end{array}$ & 9 & 18 & 0.72 \\
\hline $\begin{array}{l}10+560- \\
10+580\end{array}$ & 7 & 14 & 0.56 \\
\hline
\end{tabular}

Table 3.3 Calculation of Weighted Failure (Raveling)

\begin{tabular}{|c|c|c|c|}
\hline $\begin{array}{l}\text { Chainage } \\
\text { (m) }\end{array}$ & $\begin{array}{l}\text { Raveling } \\
\text { (m) }\end{array}$ & $\begin{array}{l}\text { Percentage } \\
\text { of raveling } \\
(\%)\end{array}$ & $\begin{array}{l}\text { Weighted } \\
\text { failure= } \\
(\% \quad \text { of } \\
\text { raveling } \\
\times 0.25)\end{array}$ \\
\hline $\begin{array}{l}0+040- \\
0+060\end{array}$ & 15 & 0.10 & 0.0020 \\
\hline $\begin{array}{l}0+120- \\
0+140\end{array}$ & 10 & 0.09 & 0.0018 \\
\hline $\begin{array}{l}0+300- \\
0+320\end{array}$ & 15 & 0.10 & 0.0020 \\
\hline $\begin{array}{l}0+780- \\
0+800\end{array}$ & 6 & 0.05 & 0.0010 \\
\hline $\begin{array}{l}1+200- \\
1+220\end{array}$ & 5 & 0.04 & 0.0008 \\
\hline $\begin{array}{l}2+820- \\
2+840\end{array}$ & 6 & 0.05 & 0.0010 \\
\hline $\begin{array}{l}3+100- \\
3+120\end{array}$ & 5 & 0.04 & 0.0008 \\
\hline $\begin{array}{l}4+480- \\
4+500\end{array}$ & 7 & 0.06 & 0.0012 \\
\hline $\begin{array}{l}5+400- \\
5+420\end{array}$ & 7 & 0.06 & 0.0012 \\
\hline $\begin{array}{l}6+940- \\
6+960 \\
\end{array}$ & 6 & 0.05 & 0.0010 \\
\hline $\begin{array}{l}7+760- \\
7+780\end{array}$ & 9 & 0.08 & 0.0016 \\
\hline $\begin{array}{l}8+600- \\
8+620\end{array}$ & 7 & 0.06 & 0.0012 \\
\hline $\begin{array}{l}10+020- \\
10+040\end{array}$ & 10 & 0.09 & 0.0018 \\
\hline
\end{tabular}

Table 3.1 Calculation of Weighted Failure (pothole)

\begin{tabular}{|c|c|c|c|}
\hline $\begin{array}{l}\text { Chainage } \\
\text { (m) }\end{array}$ & $\begin{array}{l}\text { Potholes } \\
\text { (no) }\end{array}$ & $\begin{array}{l}\text { Percentage } \\
\text { of pothole } \\
(\%)\end{array}$ & $\begin{array}{l}\text { Weighted } \\
\text { failure }=(\% \\
\text { of pothole } \\
\times 0.25)\end{array}$ \\
\hline $\begin{array}{l}0+220- \\
0+240\end{array}$ & 8 & 16 & 0.64 \\
\hline $\begin{array}{l}0+280- \\
0+300\end{array}$ & 10 & 20 & 0.80 \\
\hline $\begin{array}{l}0+780- \\
0+800\end{array}$ & 6 & 12 & 0.48 \\
\hline $\begin{array}{l}1+480- \\
1+500\end{array}$ & 10 & 20 & 0.80 \\
\hline $\begin{array}{l}2+780- \\
2+800\end{array}$ & 6 & 12 & 0.48 \\
\hline $\begin{array}{l}3+460- \\
3+480\end{array}$ & 7 & 14 & 0.56 \\
\hline $\begin{array}{l}4+500- \\
4+520\end{array}$ & 6 & 12 & 0.48 \\
\hline $\begin{array}{l}4+580- \\
4+600\end{array}$ & 7 & 14 & 0.56 \\
\hline $\begin{array}{l}5+240- \\
5+260\end{array}$ & 8 & 16 & 0.64 \\
\hline $\begin{array}{l}6+420- \\
6+440\end{array}$ & 12 & 24 & 0.96 \\
\hline $\begin{array}{l}7+380- \\
7+400\end{array}$ & 10 & 20 & 0.80 \\
\hline $\begin{array}{l}8+940- \\
8+960\end{array}$ & 10 & 20 & 0.80 \\
\hline $\begin{array}{l}9+140- \\
9+160\end{array}$ & 6 & 12 & 0.48 \\
\hline $\begin{array}{l}9+580- \\
9+600\end{array}$ & 8 & 16 & 0.64 \\
\hline
\end{tabular}

Table 3.4 Summary of Weighted Failure Obtained From Warawa to Laraba Road

\begin{tabular}{|l|l|}
\hline Failure type & Weighted failure \\
\hline Cracking & 2.098 \\
\hline Pothole & 9.360 \\
\hline Raveling & 0.016 \\
\hline Total weighted failure & 11.474 \\
\hline
\end{tabular}




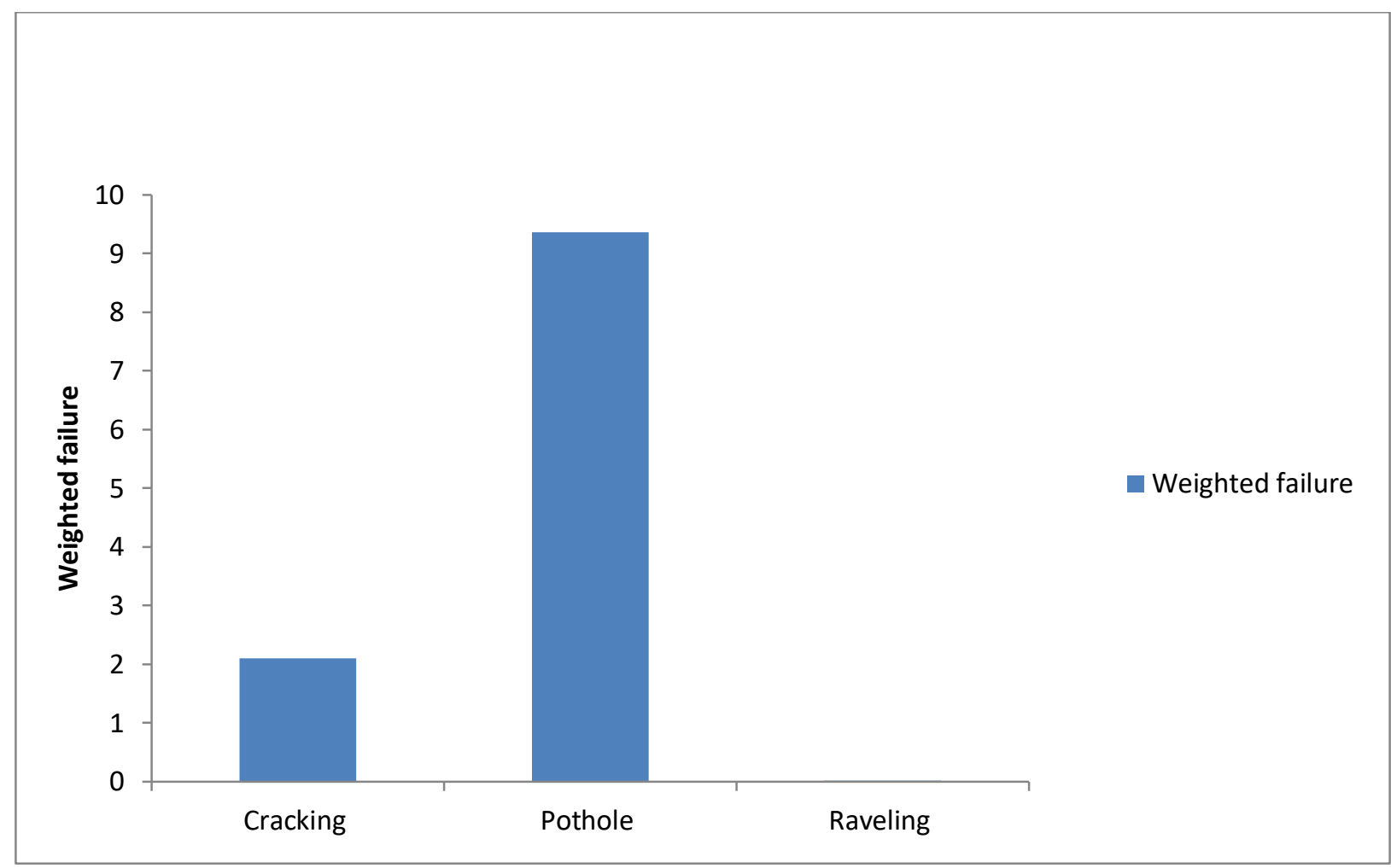

Figure 3.0: Weighted failure versus Distress Pattern

\subsection{DISCUSSION OF RESULTS}

After conducting the visual condition survey, the prevalent defects observed are cracking, potholes and raveling. The critical values among the defect were analyzed thoroughly in order to establish the current rating of the road surface. Weighted failure of each defect were calculated and the result are; cracking $=2.098$, pothole $=9.306$ and raveling $=0.016$. Having obtained the results, total weighted failure was also computed by summing the above results i.e. 11.474. The obtainable results were then compared with standard table 3.0 and approximate surface rating of the road system was established as 2.5

\section{CONCLUSIONS AND RECOMMENDATIONS}

\subsection{CONCLUSIONS}

After thorough analysis of the results obtained the following conclusion and recommendation were drawn;

i. Three types of failure pattern were found to be frequent on this selected portion of road system. Among the three types, potholes were the prevalent in terms of occurrence follow by cracking and lastly raveling. It was concluded that the weighted failure obtained for the respective defects are cracking $=2.098$, potholes $=9.036$, and reveling $=0.016$

ii. It was also concluded that 2.5 and 4.34 were obtained as the respective surface rating and users based rating score of this facility. Using this value, maintenance agencies can decide on prioritizing the treatment measures.

iii. Having obtained the rating score, of the case study to be 2.4 careful comparisons with standard table 3.1 and 3.2 was done in order to establish suitable treatment measures.

\subsection{RECOMMENDATIONS}

Finally the suggested maintenance or treatments are:

i. It is recommended that the rating indices, which were developed using appropriate method, should serve as a guide to any maintenance and other relevant agencies in finding out suitable treatment to these defects.

ii. It is also recommended to implore more sophisticated equipment and methods. This 


\section{International Journal of Engineering Applied Sciences and Technology, 2020 \\ Vol. 4, Issue 12, ISSN No. 2455-2143, Pages 28-35 \\ Published Online April 2020 in IJEAST (http://www.ijeast.com)}

effort will help in covering large distance road and consequently more realistic results could be obtained.

iii. It is also recommended that the road need full depth reconstruction with extensive base repair using the rating score obtained.

\section{ACKNOWLEDGEMENTS}

I wish to acknowledge Mustapha Garba and Kabiru A Farouk for their supervision. I also wish to thank A. Zaid, FL Zubair, AB Abdulkarim and SH Jido for their contribution in making this research published.

\section{REFERENCES.}

1. Ahmed A. (2008), Pavement Distresses Study: Identification and Maintenance (case study), M.Sc. thesis, University of Sudan.

2. Bello A. A. and Adegoke C.W. (2010) "Evaluation of Geotechnical Properties of Ilesha East Southwestern Nigeria's Lateritic Soils", Pacific Journal of Science and Technology, 11(2): (pp.617-624).

3. Bello A. A.; Ige J. A. and Adebanjo A. A. (2015). "Flexible Pavement Assessment of selected Highways in Orolu Local Government South Western Nigeria," British Journal of Applied Science \& Technology, 7(1): (pp. 45-61).

4. Bhanot K. L. and Sehgal S.B. (1983).A Text Book on Highway Engineering and Airport. 3rd.ed. New Delhi:S.Chand and Company Ltd.

5. Caltrans, (2001). Flexible Pavement Rehabilitation Manual, California Department of Transportation, Sacramento, CA.

6. Chukweze H.O. (1988). Pavement Failures caused by Soil Erosionl- Proceedings, International Conference on Case histories in Geotechnical Engineering. St Louis, (pp. 393-935).

7. Jegede G. (1995), - Soils Erosion effect on Highway Pavement Failures in Iloda locality, South western Nigeria \|. Proceedings UNESCO-MAB regional training workshop, Akure, Nigeria. (pp. 319 -322 ).

8. Kumar P. and Gupta A. (2010), "Cases studies of bituminous pavements," Compendium of Papers from the First
International Conference on Pavement Preservation. Chapter 7, paper 52, (pp. $505-$ 518).

9. Ola S. A (1978) "Geotechnical Properties and Behaviour of some Stabilized Nigeria lateritic soils" Engineering Geology 12: (pp.146-160).

10. Rogeral. Brockenbrough (2003): Highway Engineering Handbook.2ed., New York, McGraw-Hill Companies, Inc.

11. Singh A.P. (1997). Highway Engineering. 1st. ed. New Dehli: Satya Prankashan Co.Source : DOT Distress identification manual, 2003 National asphalt pavement association, (2001) NAPA.

12. Jain S. and Kumar P. (1998) "Report on Causes of Cracks Occurrence in Ramghat Aligarh Road in U.P.," Report Submitted to PWD, Aligarh.

13. Yoder E. J., and Witczak, M.W. (1975). Principles of Pavement Design, Wiley, New York.

14. Woods W. and Adcox A., (2004) "A General Characterization of Pavement System Failures, with Emphasis on a Method for Selecting a Repair Process," Journal of Construction Education, Vol. 7, No. 1, (pp. 58 - 62). 